\title{
Legal Responsibility Against Advertisement That Violating Ethics Andregulations
}

\author{
Syarifuddin Noor, BadriyahRifai, Nurhayatiabbas, Ahmadi Miru \\ Graduate School, Hasanuddin University, Indonesia
}

\begin{abstract}
The large cost of advertising, especially in Indonesia is due to the enormous potential of the Indonesian market. Therefore, advertising as one means of promotion should convey to consumers information on a product clearly, honestly and responsibly. This research was a normative and empirical research that refers to legal or ethical norms. The results shows that two parties that are strongly involved in this case are advertiser and advertising company. Advertiser as main source of information related to the advertised product. On the other hand, the advertising company is managed by people who are educated specifically or professionally in their field. Advertiser conducts a briefing to the advertising company, which then submits proposals in the form of advertising strategy. As a recommendation, it is expected that the government can cooperate with private parties to conduct an integrated and effective socialization in order to raise the legal awareness of consumer society regarding their rights and obligations as consumers.
\end{abstract}

Keywords: Advertisement, Ethics, Law Enforcement, Regulation

\section{INTRODUCTION}

For economic level, especially on the aspects of marketing, advertising or promotions are in important position. Every company in marketing the product always allocates special funds for advertising purposes. The mobility and creativity of advertising is very high, and the delivery of information through the media is so intense and sometimes sensational, not infrequently penetrate the limit of rationality. The large of spending on advertising costs is a logical consequence of business competition, which is not impossible to cause risks. ${ }^{1}$

There is no many data can be used as a reference to support the direct correlation between advertising and sales level, so that advertising cannot be used as a determinant factor to increase sales of a product or service. In the world of marketing, it is recognized there are many factors that support each other to increase sales level and advertising is one aspect that is quite dominant in the business. In fact, the variety and frequency of advertisements that visiting consumers, as well as the cost spent on advertising, both through print- and electronic media show an increasing graph. ${ }^{2}$

In juridical aspect, the transaction made by the consumer is a civic engagement. In the perspective of civil law, the engagement of consumer does not just happen but there is a prologue that precedes it. The consumer's engagement itself is an implementation of the previous engagement, which can be referred to as precontractual. ${ }^{3}$ Once pre-contractual is implemented, there is still another engagement that both parties must meet, which can be called post-contractual. The stage of consumer pre-contractual is usually marked by offers from sellers to potential buyers. Many ways is taken by business actors in offering the product or service to customers, one of which is advertising.

Advertising becomes a modern business phenomenon. No company wants to go ahead and win business competition without relying on advertising. So important is the role of advertising in modern business so that one measure of benefited corporate lies in how much money is allocated to the advertising. From year to year, advertising spending in Indonesia increased by an average of $20 \%$ to $30 \%$ annually. Chairman of Persatuan Perusahaan Periklanan Indonesia (P3I) Harris Thajeb said, until December 2014, the projected value of advertising spending of Rp. 150 trillion or grow 20 percent compared to 2013 with the achievement of Rp. 124 trillion. The biggest contribution came from the television media with 66 percent contribution. Then, print media 30 percent and the radio and digital. ${ }^{4}$

\footnotetext{
${ }^{1}$ Taufik H. Simatupang, Aspek Periklanan Dalam Perspektif Perlindungan Konsumen, Citra Aditya Bakti, Bandung, 2004, p. 1.

${ }^{2}$ Ibid., p. 2.

${ }^{3}$ Dedi Heryanto, Perlindungan Hukum Bagi konsumen Terhadap Iklan Yang Menyesatkan, Ghalia Indonesia, Bogor, 2010. p.1

${ }^{4}$ JawaPos, Des 1, 2013, p.4 
An important note in the White Paper of the Advertising Watch Agency ${ }^{5}$ conveyed that advertising violations were aired in Indonesia and which has been decided to commit violations by the Agency in the period 2009 - 2013 (a total of 358 violation cases) are much more than in the period 2005-2008 a total of 277 violation cases. Above figures can be said there is a tendency to increase advertisement violations. In Act No. 8 of 1999 on Consumer Protection (UUPK) regulated various important things about promotion. The definition of promotion itself has been clearly defined by Article 1 point 6 the Consumer Protection Act.This matter has also been arranged clearly in Act No. 8 of 1999 on Consumer Protection, Act No. 32 of 2002 on Broadcasting, and EtikaPariwara Indonesia(EPI). However, until now there are still advertisements that violate ethics and legislation, where the contents deceive and mislead consumers.

Ahmadi Miru andSutarmanYodo ${ }^{6}$ commented on this article that from the formulation of the definition of promotion then some elements that must exist are: 1) recognition activities or information dissemination; 2) goods and/or services to be traded and being traded; 3 ) the purpose of attracting buying interest from consumers. This understanding appears to be compatible with the business practice, which not only introduces or disseminates information on goods and/or services to be traded, but also trade activities.

By the presence of rules concerning advertisement in terms of ethics and laws and regulations that violate ethics and laws and regulations, all rights and obligations and responsibilities of advertisers must be explicit and clear. Article 17 paragraph (1) of Act No. 8 of 1999 on Consumer Protection determines that advertising business actors are prohibited producing advertisements that violate advertising ethics. Violations of advertising ethics categorized as violation of law in the Consumer Protection Act can lead to legal confusion. Such a rule cannot be applied in legal practice and judges cannot impose criminal sanctions based on ethical violations.

\section{METHOD OF RESEARCH}

The research about legal responsibility for advertising that violates ethics and legislation is a normative and empirical research that refers to legal or ethical norms relating to research issues. It is conducted in DKI Jakarta with the consideration that the advertising business activities are mostly found in Jakarta as the capital of the Republic of Indonesia.

\section{The Position of Advertising from Engagement Legal Aspect}

III. RESULTS AND DISCUSSION

Advertising is one means for consumers to recognize the goods or services offered by the business actor as advertiser. The consumer has the right to have the right information and to choose the product to buy. For producers, advertising is part of their product marketing activities and it will be considered successful if occur increase in sales of products/services offered. Advertising is information and non-personal communication structures that are usually financed and is persuasive about products (goods, services, and ideas) by identified sponsors, through various media. ${ }^{7}$

Advertising is part of the promotion mix and promotion mix is part of the marketing mix. ${ }^{8}$ RatnaPanjaitan ${ }^{9}$ an advertising practitioner explained that as part of the marketing mix, together with other elements in the promotion mix, advertising serves to convey a message or promise about a product/service in a creative and persuasive way to attract target to use the products/services advertised through the mass media.

Conventionally, advertising is distinguished by publicity in terms of paid and unpaid, that advertisements by media are made by accepting payments from advertisers, while publicity without payment. Advertising is one way to promote a product. In addition to advertising, there are still many other forms of promotion that have a role that is not less important in marketing strategies such as sales promotion, sampling and more.

Based on a survey by author on 50 consumers in Jakarta it appears that none of the respondents who never exposed to advertising. ${ }^{10}$ Ads reach out and pursue consumers wherever they are in the home, public places in airplanes, over the internet and so on for 24 hours. Thus, advertising undeniably plays an important role in influencing consumer behavior, particularly buying behavior or shopping, this is in line with the definition made by BadanEtikaPariwara or Advertising Ethics Board that advertisements are made to influence their target in order for them to respond appropriately to the advertisers'purposes.

\footnotetext{
${ }^{5}$ The White Paper contains the Performance Report of BadanPengawasPeriklanan (P3I) 2009 to 2013 based on the routine report to Central Executive of P3I 2009 - 2013

${ }^{6}$ Ahmadi Miru\&SutarmanYodo,2011, HukumPerlindunganKonsumen, Jakarta: PT.RadjaGrafindoPersada, p.14

${ }^{7}$ Ratna Noviani, 2002, Jalan Tengah Memahami Iklan, Pustaka Pelajar Yogyakarta.p.22.

${ }^{8}$ Rhenald Khasali, 1992, Manajemen Periklanan: Konsep dan Aplikasinya di Indonesia, Jakarta:Pustaka Utama Grafiti, p.5

${ }^{9}$ Interview and discussion with RatnaPanjaitan, Pelaku Usaha Periklanan, 15 March 2015.

${ }^{10}$ Source: Survey of author about consumer, April 2016 
The purpose of advertiser will determine the communication strategy that will be used in the advertisement. The final purpose of an advertisement is certainly to increase sales. This can be achieved through several ways, among others by encouraging the target to switch to the advertised product, persuading consumers to try new products advertised, by increasing awareness of the product or brand and so forth. In its implementation, the advertisement is installed in a variety of media options tailored to the type of products advertised and target groups that are targeted by marketing. Each media has its own character and strength in messaging.

Of course, the provisions contained in the articles of the Civil Code can be used as a legal basis in providing protection to consumers, namely by making the misdirection of information an advertisement as an act that can cause disability to the element of agreement regarding the validity of an agreement. With the existence of fraudulent elements in the advertising information submitted to the consumer, then the agreement in the form of transactions that occur between consumers and business actors contain disability, so that it can be used as a reason for consumers to request the cancellation of transactions that have occurred and filed a claim for indemnification.

As the author has described above, it can be seen that everyone have seen, heard or read advertisements either through electronic media, print media or outdoor media. Thus, the ads are clearly has a strong impact on the attitudes and behavior of the community. In the next questionnaire it appears that advertising has two opposite sides, in one side the ad is considered a positive thing but on the other side is also considered to have a negative side (Table 1).

Table 1. Consumer'sopinion about advertising

\begin{tabular}{|c|l|c|c|}
\hline No & \multicolumn{1}{|c|}{ Description } & Agree & Disagree \\
\hline 1 & Help convince in choosing & $64 \%$ & $36 \%$ \\
\hline 2 & Increase knowledge & $72 \%$ & $28 \%$ \\
\hline 3 & Educative & $26 \%$ & $74 \%$ \\
\hline 4 & Not realistic & $60 \%$ & $40 \%$ \\
\hline 5 & Creative and entertaining & $78 \%$ & $22 \%$ \\
\hline 6 & Clear message & $60 \%$ & $40 \%$ \\
\hline 7 & Not interfere with TV viewing & $38 \%$ & $62 \%$ \\
\hline 8 & Its product is not suitable & $60 \%$ & $40 \%$ \\
\hline 9 & Make life consumptive & $72 \%$ & $28 \%$ \\
\hline 10 & Not culturally appropriate & $42 \%$ & $58 \%$ \\
\hline 11 & Misleading & $64 \%$ & $36 \%$ \\
\hline 12 & Make a false promise & $66 \%$ & $34 \%$ \\
\hline 13 & Over/hyperbolization & $62 \%$ & $38 \%$ \\
\hline
\end{tabular}

Source: Consumer's survey, 2016.

As table above it can be seen that several positive aspects of advertising are that "Ads help convince consumers to choose the products they buy." It is agreed by $64 \%$ respondents, "Creative and entertaining" by $82 \%$ respondents. On the other hand, several negative aspects of advertising are "hyperbolization"is chosen by $62 \%$ respondents, "false promises" by $66 \%$ respondents.Hyperbolization and false promises can be categorized as misleading information through advertising. This may be the basis for claiming the responsibility of advertiser either based on breach of contract or unlawful deeds, by providing indemnificationto the consumer, if it causes or has caused loss to the consumer.

The possibility for consumers to file indemnificationrelated to advertising information misdirection, put forward by Ahmadi Miru and SutarmanYodo, based on a court decision stating that information obtained by consumers through brochures can be the evidence the judge considers in a consumer lawsuit against the producer. ${ }^{11}$ In fact, the actions of producers in the form of informational delivery through brochures incorrectly harming the consumer are categorized as breach of contract. Because the brochure is considered as an offer and promises are contractual, so the contents of brochure are considered to be promised in the sale and purchase, although not explicitly stated. ${ }^{12}$

The argument above puts the promises contained in similar brochure with the promises contained in a contract. Thus, the act of business actor deviating from the promises in the brochure may be considered as a breach of contract. So that,the consumers can file a lawsuit against the parties related to advertising activities by using the mechanism of breach of contract. Therefore, consumer protection is not just physical protection but a protection to abstract rights, meaning that consumer protection is in fact identical to the protection provided by the law on consumer rights.

Rights and obligations are anatomical in law, so the obligations of business actors can be seen as consumer rights. Consumers are also entitled to protection from the negative consequences of unfair

\footnotetext{
${ }^{11}$ Decision of State Court South Jakarta No. 103/Pdt.G/1997/PN.Jaksel in Ahmadi Miru\&SutarmanYodo, 2011, Jakarta:PT.GarfindoPersada, p.55

${ }^{12}$ Decision of State Court Surabaya No.502/PDT.G/1991/PN.SBY, p.56

DOI: 10.9790/0837-2206055560 www.iosrjournals.org 
competition, this can occur as a result of the business activities of the business actor who is sometimes done dishonestly. According to Handoyo, ${ }^{13}$ Chairman of the Advertising Supervisory Board, the Indonesian Advertising Company Association and the Indonesia Advertising Ethics states that ads conveys untrue information and deceives consumers is clearly contrary to Indonesias' advertising principles, that advertisers and advertisers must: a) honest, true, and responsible; d) compete in a healthy manner; c) protecting and respecting stakeholders, not undermining religion, culture, State, and class, and not contrary to law. The relationship of consumer and business actors should be balanced, meaning to be balanced if there is justice and good faith in carrying out buying and selling activities, because everyone has the same status in law. In the relationship between business actors and consumers, there are principles that arise because it is the principle of Caveat Emptor which requires consumers to be careful in purchasing a product of goods or services, especially in food products to be consumed by consumers, and Caveat Venditor who wants business actors in order to produce and market a product must pay attention to the interests of the public and provide clear information to consumers about the products it as marketed and responsible for any losses caused by its products.

\section{Legal Responsibility for Advertisement that Violate Ethics and Regulations}

To produce an advertisement, it takes role of several parties, starting from advertisers, advertising companies, and mass media, where each party can contribute in the process of making until the ads serving in mass media.In advertising activities, advertising laws should be a guideline not to be realized, so the issue of determining these responsibilities must be done case by case, depending on the role of each party. Beside, the portion of responsibility also depends on how Badan Penyelesaian Sengketa Konsumen(BPSK) or judge in the court putting the burden of responsibility for the business actor who examined.

Hence, the accountability of the parties is determined on the basis of the active role related to the source of information in the process of making the advertisement. If the source of information comes from an advertiser as product-owner, then the responsibility will be charged to the advertiser of advertising information that violating ethics and legislation. Whereas if the source of information comes from an advertiser, but the ads is created by the advertising company on its own initiative and creativity without the advertisers' consent, then the responsibility is charged to the advertising company. In addition, if the source of information contained in the advertisement is different from the original information due to advertising media mistakes, then the responsibility for advertising information in violation of the legislation in the advertising media.

In the field of law,legal responsibility is intended as an attachment to the provisions of the law. ${ }^{14}$ In the field of civil law, especially concerning consumer protection, one of the most crucial types of responsibility is related to the accountability of advertising business actors. For a business actor who conducts profit-oriented business activities for himself and his partnership it is natural that he should be responsible or bear the risks resulting from his business activities. Therefore, for business actor, especially advertising business actor must be responsible if advertisement reaching the consumer violate ethics and regulation of law.

Referring to the above description, the accountability of business actors related to advertising (producers, advertising agencies, and advertising media) is very dependent on the role of each party in producing an advertisement. The most important and decisive role is on the producer side. It is said that because the delivery of an advertisement, including the completeness and correctness of the information contained therein, must be approved by the advertiser. As long as advertising agencies and advertising media work in accordance with the directions and instructions of advertisers or manufacturers as agreed, the responsibility of responsibility is in the hands of the producers.

The advertising business actor or Advertising Company is defined by the Indonesian Advertising Council in the Book of Indonesian Advertising Ethics as "a business organization whose possessing expertise and service in the field of advertising to promote the brand, for and on behalf of the advertiser by obtaining earn for its services. ${ }^{\prime 15}$ As above definition it appears that the Indonesian Advertising Board ${ }^{16}$ clearly states through the phrase "for and on behalf of advertisers by obtaining earn" that the advertising business actor creates advertising on request and for and on behalf of the advertiser. It appears that the Indonesian Advertising Board wants to shift all advertiser's responsibility, thus the responsibility for advertising is not the Advertising Business Actor, but the producer.In a study that the authors do through questionnaires on respondents from Advertising Company, all respondents claimed to get a briefing from the advertiser producer. ${ }^{17}$ All respondents

\footnotetext{
${ }^{13}$ Interview with RidwanHandoyo as Chairman of BadanPengawasPeriklanan (BPP) P3I and an arranger member of EPI (the Indonesia Advertising Ethics), March, 15, 2016.

${ }^{14}$ Bernadette M. Waluyo, 1997, HukumPerlindunganKonsumen, Parahyangan University, Bandung, p.97.

${ }^{15}$ The Indonesia Advertising Council, A Book of Indonesia Advertising Ethics, p.15

${ }^{16}$ Association of advertising actor includes eleven associations: P3I, SPS, AMLI, APPINA, ATVSI, ATVLI, GPBSI, IDA, IPFII, PRSNI, TVRI

${ }^{17}$ Source: Survey P.U. Periklanan, April 2016. Data processed 
of advertising company in the survey said they received a briefing from the client or producer before producing the advertisement. Thus, it can be said that the source of information from advertisements produced by the ads agency is the information and guidance of the advertiser business.

However, it should be notedthat the proposal made by the advertising agency must be approved by the advertiser, according to the authors at the point of mandatory approval of the advertiser. This responsibility is shifted to the advertiser, because without the consent of the advertiser, the ads will never be produced.

Advertising actor has a professional liability not to just accept without briefing form advertiser, and without studying and checking the truth of information from the advertiser. It is the professional obligation of the advertising agency to question or inquire about the accuracy of the information it receives. Misunderstanding or ignorance or "just accept" can make the advertising agency to be "participate"in produce the ads that violate ethics and statutory provisions, said author.

Hence, the accountability of the parties is determined based on the active role as a source of information in the process of making these ads. If the source of information is from an advertiser as a product producer, then the liability shall be liable to the advertiser for advertising in violation of such laws and ethics. In contrary, the source of information comes from the advertising company and is made without the knowledge or approval of the advertiser, and then the liability shall be liable to the advertising company. In addition, if the source information contained in the advertisement is different from the original information due to the media mistake of ads, then the liability for the violated information is on the advertising media side.

The obligations of the parties to advertising activities for civil liability may arise based on contractual liability or product liability, as well as professional liability. The utilization of these 3 (three) forms of liability is tailored to the party to be held accountable and to see the availability of contract as the basis for filing the claim.

\section{Contractual liability}

Contractual liability is a "civil liability on a basis of contractual from a business actor for the loss suffered by a consumer by consuming the goods or using services. Thus, the characteristic and liability of this contractual is the existence of contractual relationships in the form of contracts as the legal basis governing the relationship of business actor with the consumer.

The development of contractual liability is strongly influenced by the principle of privity of contract, that the business actor only has an obligation to protect the consumer if there is a contractual relationship between the business actor and the consumer. In addition, the business actor is not to be blamed for any matters outside of the contract and the consumer may only claim as the breach of contract. If there is no contractual relationship, then the business actor cannot be held accountable (no privity-no liability principle).

\section{Product liability}

As the positive law in Indonesia, a consumer if loosed by consuming goods and/or services may claim the party, which causes harm. Similarly, for every business actor is required to take responsibility for the products produced or traded to consumers. Agnes M. Toar defines the product liability as the responsibility of the producers for the products it carries into circulation, causing harm due to the defects attached to the product. ${ }^{18}$

Product liability as a civil liability and goods producer (other parties may be in the distribution chain) to indemnify certain parties (may be buyers, users, or even third parties) for damage to objects, injury and/or death as a result of using the products produced by the manufacturer or producer. ${ }^{19}$ This product liability arises due to the loss suffered by the consumer as a result and the defective product due to inaccuracy in the production, inappropriate with the promised/guarantee, or the mistake made by the business actor. ${ }^{20}$ Product liability is initially applied to product defects caused by mistakes in the production process. Consumers, in this case just enough to prove that the products they consumed are indeed defective and cause harm to him/her. ${ }^{21}$

\section{Professional liability}

If the product liability is more directed to the product of business actor in the form of goods, then the professional liability is addressed to the business actor products in the form of services. According to Kantaatmaja, professional liability is legal liability in relation to professional services provided to clients. ${ }^{22}$

\footnotetext{
${ }^{18}$ Sidarta, 2000,Hukum Perlindungan Konsumen Indonesia, Jakarta, PT Grasindo, p.65

${ }^{19}$ Johanes Gunawan, 1999, Tanggung Jawab Pelaku Usaha Menurut Undang-Undang No.8/1999 tentang Perlindungan Konsumen,Jurnal Hukum Bisnis, Vol 8, p.123

${ }^{20}$ Rachmadi Usman, Hukum Ekonomi Dalam Dinamika, Jakarta:Djambatan, 2000 p.217

${ }^{21}$ In line with the liability of business actors, UUPK shall also regulate the rights of business actors, including exempting business actors from liability for losses suffered by consumers even though losses arise from defects in the product.

${ }^{22}$ KomarKantaatmaja, TanggungJawabProfesional, as cited onSidartha, Op Cit, p.67 
The characteristic of the professional liability institution is for the liability of the service provider, so that the application of this liability institution in requesting the business actor is more directed to advertising companies and advertising media, which in carrying out their business activities requires special skills. With the special expertise of advertising companies and advertising media, the advertisers' desire to introduce their products while increasing sales can be met.As a benchmark in providing services, usually each business service provider has established a professional code of ethics as a guideline of behavior and supervision respectively. As well as the Indonesian Advertising Ethics for advertising companies and the Indonesian medical code of ethics for the medical profession.

Main problem in this professional liability may arise due to business actor of service provider does not comply with the agreement that has been agreed with the client (beach of conflict), or the negligence of the service provider causing the unlawful act (onrechtmatigedaad). In advertising activities, the professional liability of advertising companies and advertising media is not only limited to the liability of the client or the advertiser, but also the liability of the professional carrier to the third party for the services it provides in this consumer society. Based on this, the legal basis of professional liability to the client may be divided into: First, under the law of agreement; Second, based on the law against unlawful acts against third parties.

With the expanded accountability of the business actor, the liability of the advertising and advertising media companies is not only to the advertisers but also the liability of the advertisement consumers. In performing its duties, advertising and advertising media companies not only consider the interests of advertisers, but also the consumers by always checking the truth of any advertising information it receives, and consider the impact of advertising creativity on consumers.

\section{CONCLUSION}

In the aspect of engagement law, the advertisement may be referred to as an offer that contains the promise of the business actor to the consumer regarding the advertised product. When the consumer makes a transaction by purchasing the product, then a contractual relationship or engagement as set forth in the contract law, although not made in writing among consumers who buy products/services offered with advertisers. The engagement relationship between both is subject to the principles and provisions of the contract law, including its legal consequences.In this research known that the parties work under an Advertising Cooperation Agreement to manage the rights and obligations of each party in detail. From the legal aspect, the statement of agreement is the transfer of legal liability of the advertiser to the advertising company. Thus, it can be concluded that the legal liability is on the side of the advertiser, although the Consumer Protection Act specifically regulates the liabilities of business actors.

As a recommendation, it is expected that the government can cooperate with private parties to conduct an integrated and effective socialization in order to raise the legal awareness of consumer society regarding their rights and obligations as consumers. Thus, it is expected that the legal society will assist in the establishment of law and ethics related to advertising and legislation. Thus, it is expected that the consumer society is not vulnerable to exploitation, but participate and active in creating a harmonious relationship between consumers and business actors.

\section{REFERENCES}

[1] Ahmadi Miru\&SutarmanYodo,2011, HukumPerlindunganKonsumen, Jakarta: PT.Raja GrafindoPersada.

[2] Bernadette M. Waluyo, 1997, HukumPerlindunganKonsumen, Parahyangan University, Bandung.

[3] Decision of State Court South Jakarta No. 103/Pdt.G/1997/PN.Jaksel

[4] Decision of State Court Surabaya No.502/PDT.G/1991/PN.SBY

[5] Dedi Heryanto, 2010, Perlindungan Hukum Bagi konsumen Terhadap Iklan Yang Menyesatkan, Ghalia Indonesia, Bogor.

[6] JawaPos, Des 1, 2013.

[7] ohanes Gunawan, 1999, Tanggung Jawab Pelaku Usaha Menurut Undang-Undang No.8/1999 tentang Perlindungan Konsumen, Jurnal Hukum Bisnis, Vol 8, p.123

[8] Rachmadi Usman, 2000, Hukum Ekonomi Dalam Dinamika, Jakarta: Djambatan.

[9] Ratna Noviani, 2002, Jalan Tengah Memahami Iklan, Pustaka Pelajar Yogyakarta.

[10] Rhenald Khasali, 1992, Manajemen Periklanan: Konsep dan Aplikasinya di Indonesia, Jakarta:Pustaka Utama Grafiti.

[11] Sidarta, 2000, Hukum Perlindungan Konsumen Indonesia, Jakarta, PT Grasindo.

[12] Taufik H. Simatupang, 2004, Aspek Periklanan Dalam Perspektif Perlindungan Konsumen, Citra Aditya Bakti, Bandung.

[13] The Indonesia Advertising Council, A Book of Indonesia Advertising Ethics.

[14] The White Paper contains the Performance Report of BadanPengawasPeriklanan (P3I) 2009 to 2013 based on the routine report to Central Executive of P3I 2009 - 2013 